\title{
Orędzie głoszone przez Jezusa Chrystusa
}

Orędzie, określane także mianem kerygmatu, obejmuje akt i treść przepowiadania zbawienia dokonanego przez Jezusa Chrystusa. Jest też formą przepowiadania, przez które Bóg w Chrystusie zwraca się do człowieka z wezwaniem, oczekując jego odpowiedzi. Orędzie to nazywamy też Ewangelią - Dobrą Nowiną ${ }^{1}$. Na początku swej działalności Jezus pojawił się w roli proroka - herolda Jahwe. W tej roli nieznacznie poprzedził Go Jan Chrzciciel (Łk 3, 1-2). O ile kerygmat Jana Chrzciciela był przedłużeniem głoszenia prorockiego Starego Testamentu, a jego treścią było wezwanie do pokuty i obwieszczenie bliskości królestwa Bożego, to w przypadku Jezusa centralnym tematem jego kerygmatu było królestwo Boże już uobecniające się dzięki Jego mesjańskiemu posłannictwu² ${ }^{2}$ Jezus rozpoczął swą działalność głoszeniem orędzia ściśle określonego, o szczególnej treści

1 A. Paciorek, Kerygmat, w: Encyklopedia Katolicka, T. 8. k. 1360-1362, Lublin 2000; J. Chmiel, Pojęcie i rola kerygmatu w pierwotnym Kościele, "Ruch Biblijny i Liturgiczny" 33 (1980) nr 1, s 59.

2 A. Jankowski, Kerygmat w Kościele Apostolskim. Nowotestamentowa teologia głoszenia Słowa Bożego, Częstochowa 1989, s. 26-28. 
i metodologii. Jezus nie tylko głosił, ale sam był Ewangelią i ewangelizatorem. „Żył tym, co głosił i głosił to, czym żył”. Styl życia potwierdzał słowa, które objawiały sens Jego działań ${ }^{3}$. Poniżej zostanie przeanalizowana treść, cel i metoda głoszenia orędzia przez Jezusa.

\section{Treść Chrystusowego orędzia}

Centralnym orędziem Jezusa było królestwo Boże $e^{4}$. Potwierdzają to synoptycy: Marek akcentuje bliskość Królestwa (Mk 1, 14-15), Mateusz Dobrą Nowinę (Mt 4,23), Łukasz podkreśla konieczność przymus (Łk 4, 43) głoszenia. Trafne ujęcie orędzia odnajdujemy w przypowieściach, w sposobie nauczania oraz w znakach. Królestwo Boże głoszone przez Jezusa nie ograniczało się do żadnego narodu, państwa, miejsca, ale było zbawczym działaniem Boga w świecie, odpowiedzią wiary, nawrócenia i posłuszeństwa Bogu, nową formą relacji międzyludzkich i oceny samego siebie. Królestwo to polega na panowaniu Boga we wszystkich dziedzinach ludzkiego życia. Ten, kto jest w Jego królestwie, jest pod panowaniem Pana ${ }^{5}$.

$\mathrm{Z}$ nauki Jezusa można także wyłonić cechy tego królestwa. Jest ono przede wszystkim misterium, rozumianym nie jako niedościgniona prawda intelektualna, ale jako rzeczywistość objawiana maluczkim

3 J. H. Prado Flores, Jak ewangelizować ochrzczonych, przeł. K. Skorulski, Łódź 1993, s. 21.

4 J. Gnilka, Jezus z Nazaretu. Orędzie i dzieje, Kraków 1997, s. 108; Określenie „królestwo Boże" pojawia się w Nowym Testamencie aż 122 razy, w tym 99 razy w ewangeliach synoptycznych, 90 razy używa tego sformułowania sam Jezus. Zob. J. Ratzinger - Benedykt XVI, Jezus z Nazaretu, cz. 1: Od chrztu w Jordanie do Przemienienia, przeł. W. Szymona, Kraków 2007, s. 51.

5 Dla ludzi Wschodu "królestwo" oznaczało rzeczywistą zdolność rządzenia i nie było pojmowane, jak na Zachodzie, w sposób abstrakcyjny. Oznaczało panowanie Boże nad ludem, który realizuje królewski ideał sprawiedliwości i polegało na tym, że Bóg posiada całkowitą władzę nad Izraelem. Królestwo Boże uobecnia się tylko tam, gdzie ludzie słuchają słowa Bożego i żyją nim. 
i prostaczkom, ludziom dobrej woli. Dla ułatwienia zrozumienia tego misterium Jezus używa obrazów i porównań, które obrazują jego elementy i cechy: zaczyn, który zakwasza ciasto (Mt 13, 33), ziarno wrzucone w ziemię (Mt 13, 3-17), ziarnko gorczycy (Mt 13, 31). Jest dziełem, które ma moc wzrastania samo w sobie (Mk 4, 26-29). Wstępu do Królestwa nie można nabyć ani zasłużyć na nie uczynkami, ale tak jak na ucztę, zaproszeni są do niego wszyscy ludzie, a szczególnie ubodzy (Mt 22, 1-9). Jest ono darem właściciela winnicy dla wszystkich pracowników, bez względu na czas pracy, zatrudnienia czy zmęczenia (Mt 20, 1-6). Są w nim dobrzy i źli, pszenica i kąkol, które muszą współistnieć aż do powtórnego przyjścia Chrystusa, podczas którego nastąpi oddzielenie jednych od drugich (Mt 22, 10; 13, 14) ${ }^{6}$. Królestwo, choć jest darem, domaga się ludzkiej odpowiedzi, tak jak gospodarz domaga się, by jego pracownicy rozliczyli się ze swych zobowiązań rolnych (Mt 21,33-43), pieniężnych (Mt 25, 14-40). Zakłada to czuwanie i oczekiwanie z zapalonymi lampami, jak dziesięć panien (Mt 25,1-13), jak słudzy oczekujący swego pana (Łk 12,36), bo przyjście jego jest bliskie (Mt 4,17) i niespodziewane (Łk 12, 40-46). Przyjdzie bowiem jak złodziej w nocy (Łk 12, 39-40), jak błyskawica, jak potop (Mt 24, 27. 37-39). Czas jest krótki, wypełnił się, a królestwo już jest wśród nas (Łk 17, 21). W tej sytuacji trzeba podjąć szybką i skuteczną decyzję: sprzedać swoje posiadłości, porzucić ludzkie zabezpieczenia i kupić drogocenną perłę, rolę, w której ukryty jest skarb (Mt 13, 44-46). Najważniejsze jest szukanie królestwa Bożego i jego sprawiedliwości a wszystko inne będzie nam dodane (por Mt 6, 33). Ofiarowane nam zbawienie jest darmowe. To dar, który pochodzi z hojności Boga. Nie można go ani nabyć, ani ukraść, ani zdobyć za zasługi, ani zasłużyć na nie. Zaproszenie na wieczną ucztę rozdawane jest na rozstaju dróg i to dla wszystkich ${ }^{7}$.

6 J. H. Prado Flores, Jak ewangelizować..., s. 22-23.

7 Por. G. Vermes, Autentyczna Ewangelia Jezusa, przeł. J. Kołak, Kraków 2009, s. 139-197. 
Jezus zburzył żydowskie wyobrażenie Boga. „Nie godził się na to by Bóg - Dawca życia zmienił się w Boga - Dłużnika, który musi płacić za zasługi i dobre uczynki (posty, dziesięciny, modlitwy itd.)" 8 . Żyd, który bał się Boga, z ust Chrystusa usłyszał, że Jahwe jest Ojcem, kochającym wszystkich ludzi, złych i dobrych, „że słońce Jego wschodzi nad złymi i nad dobrymi, i On zsyła deszcz na sprawiedliwych i niesprawiedliwych" (Mt 5, 45). Nawet więcej: szczególnie kocha zgubionych, bo posłał swego Syna nie do sprawiedliwych, ale grzeszników, bo nie zdrowi, ale chorzy potrzebują lekarza (por. Mt 9, 12-13). Bóg jest przebaczającym Ojcem zdolnym przywitać swego marnotrawnego syna. Zamiast karać go za grzechy obejmuje go, daje mu nowe ubranie i urządza ucztę (por. Łk 15, 11-32), bo „Jego miłosierdzie jest dużo większe niż największy grzech" ${ }^{9}$. Królestwo Boga jest wśród nas i w nas, w ludzkiej historii. Uobecnia się tam, gdzie jest najmniej oczekiwane: w prostytutce, złodzieju skazanym na śmierć. Rośnie dniem i nocą jak zasiane ziarno, działa jak zaczyn, który zakwasza ciasto. Nie jest spektakularne, ale małe jak ziarnko gorczycy, które przemienia się w wielkie drzewo. Jest ukrytym skarbem, którego należy szukać, drogocenną perłą, dla której należy sprzedać wszystko, co się posiada. Jest w każdej osobie i we wspólnocie, wszędzie gdzie ludzie wierzą i wzajemnie się miłują ${ }^{10}$.

Jezus głosi wartość osoby. Dla Niego każda osoba ma wartość samą w sobie, niezależnie od statusu społecznego czy religijnego, a wszystkie przepisy prawa i instytucje maja być w służbie człowieka, a nie odwrotnie. Nawet szabat i religijne struktury mają służyć człowiekowi (por. Mk 3, 1-6; 2, 23-28). Człowiek jest wartością dzięki temu, kim jest a nie dzięki temu, co posiada. Zdobywanie i uzależnianie się od bogactw jest głupotą (por. Łk 12, 13-21). W królestwie

\footnotetext{
8 J. H. Prado Flores, Jak ewangelizować..., s. 23.

9 Tamże, s. 23.

10 J. Kudasiewicz, Ewangelie synoptyczne dzisiaj, Ząbki 1999, s. 287-288; W. Kasper, Jezus Chrystus, przeł. B. Białecki, Warszawa 1983, s. 76.
} 
Bożym ceni się każdą osobę. Kobietę skazaną na śmierć za cudzołóstwo Jezus rehabilituje poprzez przebaczenie i zaufanie, że nie wróci do grzechu $(\mathrm{J} 8,1-11)^{11}$.

W królestwie Bożym nie wystarczy czynić tylko to, co uważamy za dobre, ale konieczna jest czystość intencji z którą działamy. Motywacja nadaje wartość naszym czynom. Jezus nie tolerował hipokryzji faryzeuszów, bo działali na pokaz. Aby wypełnić religijne przepisy zaniedbywali sprawiedliwość, miłosierdzie i wiarę. Dla Jezusa „podstawą jest nie to, co się robi, lecz intencja, z którą wykonuje się dane działanie"12. Wdowa, która daje wszystko co ma, daje najwięcej: „Bóg bowiem nie patrzy na to, ile dajemy, lecz ile pozostawiamy sobie"13.

Wartością w królestwie Niebieskim nie jest prawo i nakaz jego wypełniania, ale osoba Jezusa. On sam jest Dobrą Nowiną, a Jego przesłanie nie jest teorią, lecz stylem życia. On sam, zamiast mówić o przebaczeniu, przebaczał. Kochał wszystkich bez wyjątku, ubogich i grzeszników, bo „nie przyszedł, aby Mu służono, lecz aby służyć i dać swoje życie na okup za wielu" (Mt 20, 28). Czynił dobro, wprowadzał sprawiedliwość i pokój. Był królem (J 18, 37), pasterzem (J 10, 11) a jednocześnie sługą wszystkich. Nie sprzedał swej wolności na rzecz władzy politycznej czy religijnej. Nie czuł się niższy od bogatych i rządzących, ale też nie wyższy od ubogich i grzeszników. Do Boga odnosił się jak do Ojca, bo doświadczył bycia Synem Boga, w którym On ma upodobanie (por. Mt 3, 17). Był wolny od przywiązania do rzeczy materialnych, bo będąc bogaty, stał się ubogim dla nas, aby nas swoim ubóstwem ubogacić (por. 2 Kor 8, 9). Żył w zgodzie z naturą i całym stworzeniem, zwierzętami, roślinami. Pozwalał rosnąć pszenicy i kąkolowi (por. Mt 13, 24-30). Dzięki takiemu stylowi życia

11 J. H. Prado Flores, Jak ewangelizować..., s. 24.

12 Tamże, s. 25.

13 Tamże, s. 25. 
Jezus sam był orędziem. Jego życie stało się dla nas nauką: „uczcie się ode Mnie..." (Mt 11, 29) ${ }^{14}$.

Choć zaproszenie do królestwa Bożego jest darmowe, jego przyjęcie domaga się wzajemności: czujności i gotowości z zapaloną lampą, rozwijania otrzymanych talentów. Kto nie ma szaty weselnej (odpowiedniej postawy) zostanie precz wyrzucony (Mt 22, 1-14). Uczestnictwo w królestwie Bożym to nie sprawa rzeczy zewnętrznych, ale wewnętrznej przemiany określanej jako „narodzenie na nowo", przekształcenia kryteriów sądzenia i wartości.

Jezus głosząc, że miłość jest ponad Prawem i przepisami religijnym, zachwiał fundamentami religijności żydowskiej. Jadał nieobmytymi rękami, w szabat zrywał kłosy i uzdrawiał. W nowym przykazaniu nakazał nam tak samo miłować Boga jak człowieka, a siebie wzajemnie tak, jak On nas umiłował (por. J 13, 34). Warunkiem Bożego przebaczenia nam uczynił przebaczenie przez nas doznanych krzywd (Mt 5, 23-24) ${ }^{15}$.

Na drodze do Królestwa występują trzy wielkie przeszkody:

1. Wiara we własną sprawiedliwość. Przypowieść o modlitwie faryzeusza i celnika kończy się konkluzją faworyzującą skruszonego grzesznika: „Powiadam wam: Ten odszedł do domu usprawiedliwiony, nie tamten” (Łk 18, 14).

2. Ufność bogactwom a nie Bogu: „Jak trudno jest bogatym wejść do królestwa Bożego. [...] Łatwiej jest wielbłądowi przejść przez ucho igielne, niż bogatemu wejść do królestwa Bożego"(Mk 10, 23. 27).

3. Grzech, który zniewala człowieka: „Każdy, kto popełnia grzech, jest niewolnikiem grzechu" (J 8, 34).

Cechą królestwa Bożego jest jego nieustanna nowość. Nie można go zamknąć w żadnych granicach, przekracza nasze definicje i pojęcia, a każdy, kto idzie ewangeliczną drogą musi być przygotowany na

14 J. H. Prado Flores, Cómo Evangelizar a los Bautizados, México 2013, s. 20-24.

15 J. H. Prado Flores, Jak ewangelizować..., dz. cyt., s. 27. 
pokonywanie ciągle nowych dróg i wydarzeń ${ }^{16}$. Podsumowanie postaw obywateli królestwa Bożego znajdujemy w błogosławieństwach proponujących nowe wartości, które powinny rządzić relacjami międzyludzkimi i relacjami z Bogiem. Także modlitwa Ojcze nasz zbiera postawy ludzi należących do królestwa. Natomiast w siedmiu słowach wypowiedzianych z krzyża Jezus pokazuje, że żyje tym wszystkim, co głosił i podsumowuje całe swoje nauczanie ${ }^{17}$.

\section{Cel Jezusowego orędzia}

Celem misji Jezusa jest zbawienie człowieka i wszystkich ludzi. Jego imię, Jeszua (Bóg zbawia), jest streszczeniem Jego misji, co sam potwierdza w słowach: „zbawienie bierze początek od Żydów” (J 4, 22). Przedstawiając się w synagodze w Nazarecie sam streszcza swoją misję i określa przedmiot swego działania w pięciu punktach ${ }^{18}$ :

Duch Pański spoczywa na Mnie, ponieważ Mnie namaścił i posłał Mnie,

- abym ubogim niósł dobrą nowinę,

- więźniom głosił wolność,

- a niewidomym przejrzenie;

- abym uciśnionych odsyłał wolnymi,

- abym obwoływał rok łaski od Pana (Łk 4, 18-19).

Z tekstu tego dowiadujemy się, że „wypełnienie” i „Dobra Nowina” są w Jezusie, który przychodzi jako namaszczony Duchem Pańskim, by „obwoływać” swoisty jubileusz, rok darowania win. Jest to zasadniczy cel „Ewangelii królestwa”. Jezus inauguruje nadejście królestwa

16 Tamże, s. 28.

17 Tamże, s. 29.

18 A. Jankowski, Kerygmat w Kościele Apostolskim..., dz. cyt., s. 27-28. 
Bożego w swojej osobie, ogłasza koniec niewoli i dokonuje zapowiadanego zbawienia ${ }^{19}$. Głosi Ewangelię ubogim, bo jedynie ci, którzy uznają swe ubóstwo wobec Boga i będą nim żyli, mogą zostać zbawieni. Ewangelia nie ogranicza się do jednego rodzaju ludzi, jest „powszechnym zaproszeniem do ubóstwa, by w ten sposób stać się odbiorcami Dobrej Nowiny. Kto nie będzie ubogi, nie będzie mógł otrzymać bogactw królestwa" 20 .

Jezus przynosi wyzwolenie wewnętrzne, zdejmuje wewnętrzne kajdany lęku, żalu, goryczy, nieufności, egoizmu, zazdrości z których sam siebie człowiek uwolnić nie może. Przywracając wzrok ociemniałym, Jezus nie uzdrawia jedynie z fizycznej ślepoty, ale ze skutków grzechu, który utrzymuje człowieka w ciemności niewiedzy. Bez światła prawdy o Bogu, człowieku i stworzeniu żyjemy w ciemności ${ }^{21}$.

Jezus przynosi także wyzwolenie zewnętrzne. Aby wprowadzić królestwo Boże, umożliwia przemianę niesprawiedliwych struktur, zmianę zasad i wartości, które rządzą naszym życiem społecznym. Pełnia czasów jest rokiem łaski od Pana, rokiem jubileuszowym, w którym Bóg daruje nam wszystkie długi, przebacza grzechy, abyśmy i my darowali innym nasze długi.

Jezusowe zbawienie wyzwala nas z grzechu, a podstawowym skutkiem śmierci i zmartwychwstania Jezusa jest „pojednanie” - wprowadzenie pokoju w wojnie człowieka $\mathrm{z}$ Bogiem i przywrócenie stworzeniu bliskości z Jego stwórcą (por. Ef 2, 12. 14-18; Rz 5, 1). Chrystus umarł za nasze grzechy $(1$ Kor 15,3$)$ i w nim nasze grzechy zostały zgładzone ${ }^{22}$. Zbawienie jest uwolnieniem z grzechu, przywróceniem wspólnoty z Bogiem i braćmi, udzieleniem życia Bożego: „Ja przyszedłem po to, aby owce miały życie i miały je w obfitości” (J 10, 10), oraz

19 Tamże, s. 28.

20 J. H. Prado Flores, Jak ewangelizować..., dz. cyt., s. 31.

21 Tamże.

22 R. Ptak, Królestwo Boże - realizacja zbawczego planu Boga. Od "Lumen gentium" do "Novo millennio ineunte", Kraków 2006, s. 29-30. 
„Ja jestem [...] życiem” (J 14, 6). Nowe życie nie polega na wszechstronnej wiedzy, jak w przypadku Nikodema, ale bierze się ono z nowego narodzenia, które jest łaską i polega na tym, by od tego momentu żyć ideałami królestwa ${ }^{23}$.

Celem Jezusowej misji jest nowe przymierze, które nigdy nie zostanie zerwane. Jego krew obmywa nas z winy, zmartwychwstanie daje nowe życie tym, którzy wierzą w Niego. Królestwo Boże to tworzenie nowych relacji międzyludzkich, nowego ludu, wspólnoty, w której żyje się wartościami i zasadami ewangelicznym. Dlatego Jezus wybiera dwunastu, którzy stanowią zaczyn nowego Izraela. Piotr otrzymał klucze królestwa $($ Mt 16, 19) którymi miał otworzyć drzwi wiary i Żydom i poganom ${ }^{24}$. Wszyscy wierzący otrzymają Ducha Świętego, który będzie źródłem nowego życia dla dzieci Bożych, stanie się ich Parakletem - Obrońcą i zostanie na zawsze w tych, którzy go pragną (J 14, 16). On będzie aktualizował działo Jezusa w Kościele i sprawi, ze uczniowie będą czynili większe rzeczy niż sam Jezus (J 9, 14). To Duch Święty będzie dawcą i twórcą jedności w Kościele ${ }^{25}$.

\section{Metoda głoszenia orędzia}

Jezus używał skutecznej metody głoszenia Dobrej Nowiny. Cecha tej Bożej metodologii tkwi we Wcieleniu Syna Bożego, bowiem „Słowo stało się ciałem, i zamieszkało między nami” (J 1, 14). Chrystus, będąc Bogiem, zjednoczył w sobie naturę boską i ludzką, stał się ubogim wśród ubogich, przyjął postać sługi i był posłuszny Bogu. Szedł do ludzi zepchniętych na margines, bez przywilejów społecznych. Symbolami jego misji były głos i stopa (por. Iz 40, 3). Był głosem

23 J. H. Prado Flores, Jak ewangelizować..., dz. cyt., s. 35.

24 A. Jankowski, Kerygmat w Kościele Apostolskim..., dz. cyt., s. 27-28.

25 P. Spyra, Kerygmat Jezusa - Dobra Nowina o człowieku i dla człowieka, „Rocznik Teologii Katolickiej" t. XIII (2014) 1, s. 237. 
tego, który Go posłał. Jego zadaniem było dotarcie do wszystkich ludzi, do których posłał Go Ojciec. Droga była miejscem Jego misji. Przemierzył całą Galileę (Mt 4, 23) ${ }^{26}$. Był nie tylko prorokiem-heroldem, ale mistrzem i nauczycielem - rabbim ${ }^{27}$.

Nauczał dwoma sposobami: słowami i czynami. Sam był ewangelizatorem i Ewangelią (Mk 1, 1), posłaniem i posłańcem. „Żył tym, co głosił i głosił to, czym żył. Jego styl życia nigdy nie stawał w sprzeczności z Jego słowami, a zarazem one rozświetlały sens Jego działań” 28. Słowo to nie miało sobie równych. Wywoływało poruszenie i zachwyt: „Nigdy jeszcze nikt nie przemawiał tak, jak ten człowiek przemawia" (J 7, 46).

Jezus przemawiał nie tylko ustami, ale także czynami i za pomocą znaków prorockich. Każde Jego działanie było pełne Dobrej Nowiny: przebaczenie grzechów, umycie nóg, a szczególnie wydarzenia paschalne. Największym znakiem była Jego osoba. On sam był Bożym objawieniem: „Kto Mnie widzi, widzi także i Ojca” (J 14, 9) i przejawem miłości Ojca, który „nie posłał swego Syna na świat po to, aby świat potępił, ale po to, by świat został przez Niego zbawiony" (J 3, 17).

Jezus nauczał inaczej niż inni nauczyciele: „Uczył ich bowiem jak ten, który ma władzę, a nie jak ich uczeni w Piśmie” (Mt 7, 29). Dawał do zrozumienia, że nie zamierza biernie akceptować norm kulturowych i religijnych rabinów. I choć otwarcie oznajmił, że nie zmierza prawa obalić, ale uzupełnić o objawienie, którym jest On sam (por. Mt 5,17), w Jego stylu widocznych jest wiele nowych elementów.

26 U. Terrinoni, Nauczanie ewangeliczne w zarysie, przeł. R. Jaremko, Kraków 2000, s. 9-10.

27 Jezus, mimo że nie uczęszczał do szkół rabinackich, uważany był za rabbiego, bowiem każdy Izraelita, który odznaczał się zdolnościami proroczymi, mógł występować publicznie i gromadzić uczniów. Władze religijne prosiły wówczas o jakiś „dowód” dla zalegalizowania jego działalności. Ów rabbi mógł odwołać się do Pisma lub tajemniczej wizji, które powierzyły mu to zadanie. Zob. U. Terrinoni, Nauczanie ewangeliczne..., s. 11-12.

28 J. H. Prado Flores, Jak ewangelizować..., dz. cyt., s. 38. 
Odstępuje od tradycji (por. Mk 7,1-13) i dosłownego rozumienia prawa a powołuje się na swój własny autorytet i ducha Prawa ${ }^{29}$. Rabini przekazywali sobie interpretację prawa pochodzącą od Mojżesza, nauczali w jego imieniu, byli jego uczniami (por Mt 23, 2) i nie mogli prawa ani zmienić, ani wprowadzić jakichkolwiek poprawek. Jezus, szanując prawo i jego praktykowanie, kieruje uwagę uczniów nie tyle na prawo samo w sobie, ile na przeciwstawienie: „słyszeliście, że powiedziano” - „a Ja wam powiadam” (por. Mt 5, 21-39).

W Ewangelii św. Jana wiele jest wypowiedzi Jezusa z charakterystyczną formą "Ja jestem”. Dzięki niej waga i znaczenie teologiczne wypowiedzi spoczywa na Jego osobie: „Ja jestem chleb życia” (J 6, 48); "Ja jestem światłością świata” ( 8,12$)$; „Ja jestem dobrym pasterzem" (10, 11); „Ja jestem zmartwychwstaniem i życiem" (J 11, 25); "Ja jestem drogą i prawdą, i życiem” (J 14, 6); „Ja jestem prawdziwym krzewem winnym” (J 15, 1). Słowa „Ja jestem” nawiązują do słów Księgi Wyjścia „Jestem, który jestem” (Wj 3, 14) i „wskazują na wielkość, wyższość i nadprzyrodzony charakter Jezusa, który jest Bogiem, a równocześnie podkreślają Jego bliskość, skromność i prostotę”30. Kiedy Jezus wypędza demona $\mathrm{z}$ opętanego, zdumiony tłum pyta: „Co to jest? Nowa jakaś nauka z mocą" (Mk 1,27), a po uzdrowieniu paralityka „zdumiewali się wszyscy i wielbili Boga, mówiąc: jeszcze nigdy nie widzieliśmy czegoś podobnego" (Mk 2, 12).

Jezus proponuje nową naukę, ale „nowa nie oznacza wcale czegoś nigdy dotąd niepowiedzianego ani niesłyszanego. Jest nowa, bo za jej pośrednictwem człowiek zrywa z przeszłością i wkracza w nową, nieznaną dotychczas rzeczywistość, którą odkrywa jako jedyną, prawdziwą, autentyczną i od dawna upragnioną" ${ }^{31}$. W obliczu tej nauki wszystko inne jest niepotrzebne i przestarzałe. Słowo Jezusa przywraca człowiekowi młodość, świeżość, nowe życie.

29 U. Terrinoni, Nauczanie ewangeliczne..., dz. cyt., s. 15.

30 Tamże, s. 17.

31 Tamże, s. 21. 
To nauka z mocą. W imię swej mocy Jezus ogłasza się większym od największego z proroków - Jana Chrzciciela (por. Mk 11, 30-33; Mt 11, 27); większym od Jonasza (por. Mt 12, 40-41; Łk 11, 32). Uczniów zapewnia: „Szczęśliwe oczy, które widzą to, co wy widzicie. Bo powiadam wam: Wielu proroków i królów pragnęło ujrzeć to, co wy widzicie, a nie ujrzeli, i usłyszeć, co słyszycie, a nie usłyszeli” (Łk 10, 2324). Nauka ta nie jest owocem ludzkiego wysiłku, ale pełna jest mocy boskiej, bo pochodzi z wysoka. Poparta jest i siłą cudów, i stylem życia pełnym skromności, pogody ducha, pozostającym w harmonii z nauką, którą głosił. To słowo pełne mocy, które wyzwala i uzdrawia. Nie może ono pozostać bezowocne. Wymaga wprowadzenia go w życie, wzywa do działania, do czynu: „Wydajcie godny owoc nawrócenia” (Mt 3, 8). Zbawienie jest darem domagającym się naszej czynnej odpowiedzi, dlatego „Jezus przedstawia swe prawdy nie jako pojęcia, których należy się nauczyć, lecz jako fakty, czyny i zadania do spełnienia" ${ }^{32}$. Nie jest to nauka abstrakcyjna, ale nauka angażująca człowieka, w której „nawet Bóg nie jest przedstawiony jako dobroć, miłosierdzie i sprawiedliwość same w sobie, lecz jako Ten, którego działania charakteryzują te właśnie przymioty" ${ }^{33}$. Jezus sam służy, pomaga, wyzwala, uzdrawia. Realizując Boży plan, niczego nie czyni na pokaz. Nie zaspakaja ludzkiej ciekawości Heroda, który pragnął być świadkiem cudu (por. Łk 23, 8-9), faryzeuszom, którzy żądają znaku z nieba odpowiada, że „żaden znak nie będzie dany temu plemieniu" (Mt 8,11-13), a szatanowi kuszącemu Go na pustyni stanowczo oświadcza, że nie czyni cudów ani na pokaz, ani dla zaspokojenia własnej próżności. Nie chce uchodzić za cudotwórcę i nie czyni cudów dla własnej korzyści, kiedy doświadcza szyderstw na krzyżu (por. Łk 23, 35-37), ani dla wymierzenia kary dla niegościnnego miasteczka samarytańskiego (por. Łk 9, 53-55), ani na prośbę 
tłumu, pragnącego uwolnić się od codziennych zajęć i obowiązków (por. Mk 1, 35-38) ${ }^{34}$.

Swoje zamierzenia pedagogiczne realizuje nawet wtedy, gdy odpowiada na wścibskie pytania. Odpowiadając na jedno z nich: „czy tylko nieliczni będą zbawieni?”, nie zaspakaja ciekawości rozmówców, ale przenosi akcent z ilości na metodę: „Usiłujcie wejść przez ciasne drzwi” (Łk 13, 23-24). Jezus kładzie nacisk na powagę z jaką należy traktować działania prowadzące nas do zbawienia ${ }^{35}$. Kiedy uczniowie pytają, kiedy Syn Człowieczy powróci na ziemię (por. Mt 24, 3n), odpowiada, radząc jak należy przygotować się na Jego powrót i co czynić. W stosunku do zakłamanych i zadufanych faryzeuszy, którzy odwracają hierarchię wartości i przedkładają pozory i fałsz nad prawdę, Jezus stawał się nieprzejednany i bezkompromisowy a jego słowa gorzkie (por. Mk 3, 5; Mt 23).

W stylu nauczania Jezus często uciekał się do dialogu ${ }^{36}$, który sprawiał, że Jego nauki stały się ciekawe, żywe, wciągające rozmówców. Pozostając poza zasięgiem ówczesnych partii polityczny, religijnych ugrupowań był otwarty na rozmowę z każdym i od każdego przyjmował zaproszenie. Często punktem wyjścia do dialogu były rozbieżności między Jezusem a rozmówcami, negatywnie oceniane Jego gesty, cuda, zachowanie, decyzje, wypowiedzi. Odpowiadając rozmówcom „Jezus nie zadawala się samym tylko przedstawieniem własnego punktu widzenia, lecz konfrontuje go z poglądami tych wszystkich, którzy myślą inaczej” ${ }^{37}$. Dialog rozwija się zazwyczaj pośród pytań i krótkich odpowiedzi. „Argumenty początkowo ograniczone

34 C. Tresmontant, Jezus naucza, przeł. L. Rutowska, Warszawa 1973, s. 42-43; G. Vermes, Autentyczna Ewangelia Jezusa, dz. cyt., s. 139-197.

35 U. Terrinoni, Nauczanie ewangeliczne..., dz. cyt., s. 24.

36 Obszernie na ten temat pisze S. Włodarczyk, Dialog jako metoda nauczania Jezusa, „Pedagogika Katolicka" 8 (2011) nr 1, s. 78-83; tenże, Trudny dialog. Droga do wiary w Chrystusa Zbawiciela, Częstochowa 2003; S. Mędala, Ewangelia według świętego Jana (rozdz 1-12), Częstochowa 2010, s. 49.

37 U. Terrinoni, Nauczanie ewangeliczne..., dz. cyt., s. 38. 
do problemów zasadniczych, stopniowo zwiększają swój zasięg, aż w końcu dialog przybiera formę twierdzącą. Wówczas nie ma już miejsca na dyskusję, pytania i odpowiedzi. Do wyboru pozostaje «tak» lub «nie»" ${ }^{38}$. Jezus nie prowadził dialogu w nieskończoność. Ogłoszone orędzie mogło zostać przyjęte lub odrzucone bez dodatkowych pytań ${ }^{39}$. Najczęściej kierował rozmową w taki sposób, aby rozmówca sam wyciągnął wnioski, podejmował decyzję, zobowiązanie. Wypowiedzi, często formułowane w drugiej osobie liczby pojedynczej, dowodzą że interesuje się konkretnym człowiekiem, jego indywidualnym rozwojem (por. Mk 10, 17-22; J 3, 1-15; 4, 1-26). Częściej jednak zwraca się w drugiej osobie liczby mnogiej, zwłaszcza do tłumów, uczonych w Piśmie i faryzeuszów, do grona uczniów: „Jeśli bowiem miłujecie tych, którzy was miłują, cóż za nagrodę mieć będziecie? Czyż i celnicy tego nie czynią? I jeśli pozdrawiacie tylko swych braci, cóż szczególnego czynicie? Czyż i poganie tego nie czynią? Bądźcie więc wy doskonali, jak doskonały jest Ojciec wasz niebieski." (Mt 5, 46-48). Wypowiedzi tego typu są „bardziej zwięzłe, a równocześnie pełne werwy i zapału. Przybierają stanowczy ton, w którym wyczuwa się ową pilność, oczekiwanie na niezwłoczną odpowiedź, aż w końcu przyjmują formułę rozkazującą" ${ }^{40}$.

Przy okazji spotkań Chrystusa z rozmówcami odkrywamy niezmierzoną cierpliwość Boga w stosunku do człowieka i jego problemów: „Objawienie Boga nie chodzi własnymi drogami: to inkarnacja,

38 Tamże.

39 Styl dialogu Jezusa trafnie ilustruje dialog z uczonym w Prawie (Łk 10, 25-37). Po szczegółowej wymianie pytań i odpowiedzi uczony w Prawie zapytuje: „a kto jest moim bliźnim?". Wówczas Jezus rezygnuje z modelu akademickiej dysputy, intelektualnego wywodu i proponuje przeanalizowanie konkretnego wydarzenia. Opowiada historię o miłosiernym Samarytaninie i zadaje decydujące pytanie „któryż z tych trzech okazał się, według twego zdania bliźnim...?” a następnie stosuje pouczenie: „Idź i ty czyń podobnie”. W szkole Jezusa istotą nie jest wiedza, ale czyn, postępowanie. Czasownik „czynić" pojawia się w powyższej perykopie aż trzy razy.

40 U. Terrinoni, Nauczanie ewangeliczne, dz. cyt., s. 40. 
wcielenie Boga w osobę ludzką, toteż dostosowuje swój krok do kroku człowieka" ${ }^{41}$. Wybierając formę dialogu Jezus nie narzuca prawdy z zewnątrz, nie wdaje się też w dysputy filozoficzne, ale włącza do niego słuchaczy, po czym skłania ich do samodzielnego podjęcia decyzji i wyboru, bo ,jest przekonany, że każdy problem człowieka kryje coś, co wydobyte na jaw może rozjaśnić ów problem od podstaw, pomóc zrozumieć go i rozwiązać" 42 . W udzielanych odpowiedziach Jezus nie daje natychmiast ostatecznego rozwiązania, ale wprowadza nowy punkt widzenia, który pomaga dotrzeć do źródeł problemu ${ }^{43}$.

Jezus był nauczycielem wędrownym: „I obchodził Jezus całą Galileę, nauczając w tamtejszych synagogach, głosząc Ewangelię o królestwie i lecząc wszelkie choroby i wszelkie słabości wśród ludu" (Mt 4, 23). Nauczając w drodze, obchodził wszystkie krainy i prowincje. Udał się do Samarii $(Ł k$ 17, 11), a także w okolice Tyru i Sydonu $($ Mt 7, 24) Sam przejmował inicjatywę. Poszukiwał zagubionych owiec, wychodził do grzeszników, wszedł do domu Zacheusza ${ }^{44}$.

Jezus nauczał w przypowieściach: „... a bez przypowieści nie mówił do nich" (Mt 13, 34). Choć przypowieść, jako forma literacka, znana była wcześniej w tradycji rabinackiej, Jezus nadaje swym przypowieściom oryginalny kształt w zakresie treści i formy artystycznej.

41 IVangeli, Assisi 1984, str 1419, cyt. za: U. Terrinoni, Nauczanie ewangeliczne, dz. cyt., s. 41.

42 U. Terrinoni, Nauczanie ewangeliczne, s. 41.

43 Kiedyś jakiś człowiek, odwołując się do Jezusowego poczucia sprawiedliwości, prosi Go, by rozstrzygnął kwestię spadku (Łk 12, 13-21): „Nauczycielu, powiedz mojemu bratu, żeby podzielił się ze mną spadkiem", Jezus odmawia i zachęca obie strony do zgłębienia problemu, którego istotą nie jest posiadanie dóbr materialnych, ale umiejętność ich mądrego wykorzystania, ponieważ życie ludzkie nie jest od nich zależne. Kiedy uczniowie łuskają kłosy w szabat (Mk 2, 23-28), a uczeni w prawie protestują, Jezus nie daje się wciągnąć w jałową dyskusję, ale proponuje przeanalizować problem i odkryć zasadę podstawową: „To szabat został ustanowiony dla człowieka, a nie człowiek dla szabatu". Prawo nie może być jarzmem, lecz darem, ustanowione dla człowieka ma służyć jego życiu i rozwojowi. Por. U. Terrinoni, Nauczanie ewangeliczne,, s. 41-42.

44 C. Tresmontant, Jezus naucza..., dz. cyt., s. 42-43. 
Daje w nich wyraz swej poetyce, wyobraźni, zdolnościom narracyjnym. Proponuje niezwykle intensywne obrazy pulsujące życiem, prezentujące ludzi i rzeczy, które zachwycają spontanicznością, siłą oddziaływania i walorami artystycznymi. Są one poszukiwaniem istoty rzeczy i dają jej wyraz ${ }^{45}$. Jezus czerpał obrazy z życia. Za punkt wyjścia służyły mu wydarzenia z życia codziennego rybaków, pasterzy, rzemieślników, chłopów, robotników, kobiet. W ten sposób stają się bardziej zrozumiałe dla przeciętnego człowieka. Bierze przykłady z fauny i flory palestyńskiej. Punktem wyjścia dla rozważań jest źdźbło trawy, lilia polna, ziarnko gorczycy, drzewo figowe, kąkol, pszenica, ptaki powietrzne, stado owiec, wilków, kura, gołąb, kornik, uległe zwierzę juczne i zdradziecki wąż ${ }^{46}$. Przedstawiając zdarzenia z życia codziennego prostym językiem, przekazuje „słowa życia wiecznego” (J 6, 68), „słowa łaski” (Dz 14, 3) „naukę o zbawieniu” (Dz 13, 26). Siły perswazji bardziej szukał w odwołaniu się do doświadczenia słuchaczy niż do mocy autorytetu innych nauczycieli czy interpretatorów prawa. Stosował zamierzoną przesadę, wyolbrzymiał, aby zwrócić na coś uwagę, podkreślić znaczenie jakiegoś elementu: belka w oku, kamień młyński, dziesięć tysięcy talentów, wielbłąd w uchu igielnym.

Innym elementem metodologii Jezusa były pełne symboliki znaki, cuda uwolnienia i uzdrowienia. Jezus często odwoływał się do tekstów Starego Testamentu. Cytował Prawo i proroków, psalmy Dawida. Ewangelista Mateusz nieustannie podkreślał, że Jezus wypełnił wszystkie starotestamentalne obietnice prorockie i sam też porównywał się z niektórymi postaciami ze Starego Testamentu.

Jezus nie pracował sam, ale we wspólnocie. Zdecydował się na stworzenie grupy „uczniów” (Mk 1, 16-20). Utworzył wspólnotę

45 Przypowieść opiera się na zestawieniu i porównaniu sytuacji wziętej z życia codziennego z realiami życia duchowego. Wydarzenia życia doczesnego zostają skonfrontowane z sytuacjami natury religijnej, co pozwala na lepsze ich zrozumienie.

46 U. Terrinoni, Nauczanie ewangeliczne, dz. cyt., s. 53-54. 
i posłał swoich uczniów tak jak Ojciec posłał Jego. Nierozerwalną jedność Nauczyciela ze swymi uczniami podkreślał ewangelista Marek ${ }^{47}$. W szkole rabinackiej uczeń sam wybierał sobie nauczyciela, któremu służył. Jezus odbiega od tego wizerunku i sam wybiera tych, którzy idą za Nim. Pozwala podążać za sobą także kobietom (por. Łk 8, 1-3). Rezygnuje z pozycji nauczyciela, któremu służą uczniowie i woli być wśród nich „jak ten, kto służy” (Łk 22, 17) ${ }^{48}$. Uczniowie są słuchaczami i naśladowcami Jezusa, mają „trwać w nauce Jezusa $(J$ 8, 31) i wypełniać Jego słowa (Mt 7, 24). Jan Chrzciciel formował jedynie uczniów, a nie apostołów, dlatego jego dzieło zakończyło się wraz $\mathrm{z}$ jego śmiercią. Dzieło Jezusa trwać będzie aż do końca czasów ${ }^{49}$.

\section{Podsumowanie}

Jezus, podobnie jak prorocy, był posłany, by głosić słowo zlecone przez Boga. Jego posłannictwo było jednak nie tylko prorockie, ale przede wszystkim mesjańskie. Przyszedł jako namaszczony Duchem Świętym, by ogłaszać „rok łaski od Pana”, swoisty jubileusz, rok darowania win. Zasadniczą treścią Jezusowego orędzia była Dobra Nowina o królestwie Bożym, które inaugurował swoja działalnością. Jezus głosi królestwo Boże jako bliskie i nadchodzące, czynne, już wyczuwalne, związane z Jego osobą i działaniem, wołające o jasna decyzję. Królestwo to realizuje się tylko w tych, którzy słuchają i wypełniają Jego słowo. Tajemnicę królestwa Jezus głosił w przypowieściach. Chrystus w swoim orędziu i głoszonym przez siebie królestwie Bożym nie dadzą się rozdzielić. Celem Jego misji jest zbawienie wszystkich ludzi. Jego orędzie przynosi wyzwolenie wewnętrzne i zewnętrzne, jest

47 Szeroko na ten temat pisze S. Haręzga, Jezus i Jego uczniowie. Model chrześcijańskiej formacji w Ewangelii według św. Marka, Lublin 2006, s. 199-266.

48 U. Terrinoni, Nauczanie ewangeliczne, dz. cyt., s. 11-12.

49 J. H. Prado Flores, Jak ewangelizować..., dz. cyt., s. 42-43. 
uwolnieniem z grzechu, przywróceniem wspólnoty z Bogiem i braćmi, udzieleniem życia Bożego, nowym przymierzem. Zapowiedział także zesłanie Ducha Świętego. Jezus jest nauczycielem, który nie proponuje doktryny, ale siebie samego, własny model życia i postępowania. Jego przesłanie nie jest teorią, ale stylem życia. Jezus nie był komentatorem Prawa i nie podpierał się autorytetem poprzedników. Jego orędzie nie było mówieniem o Bogu, ale było słowem Bożym. On sam był Słowem Bożym. W Jego słowach obecny był autorytet Boga. Moc nauki płynęła z Niego samego, a Jego orędzie było pełnym mocy wydarzeniem, które sprawiało, że chorzy, ubodzy, zniewoleni, odrzuceni, opętani dostępowali zbawienia, przemiany, otwierali się na nową rzeczywistość i odzyskiwali samych siebie ${ }^{50}$. Siła oddziaływania Jezusa była tak wielka, że wpływała na zmianę życiowych planów, trybu życia, sposobu myślenia i działania człowieka. Jezus jako nauczyciel wędrowny nie działał sam, ale zgromadził wokół siebie uczniów, z którymi realizował ideał życia we wspólnocie. W szkole Jezusa to nie uczeń poszukiwał sobie nauczyciela, ale On sam szukał i wyzywał do siebie ucznia. W istocie uczeń nie zdobywał sobie nauczyciela, lecz sam zostawał zdobyty ${ }^{51}$. Przebywając z Jezusem, uczeń z czasem nabierał nowego stylu życia, poznawał nowe kryteria oceniania, wyborów, nową hierarchię wartości. W ten sposób przesłanie Jezusowego orędzia stało się nie tylko teorią, ale i praktyką, stylem życia najpierw Jezusa a potem Jego uczniów.

50 J. Ratzinger - Benedykt XVI, Jezus z Nazaretu..., dz. cyt., s. 265; S. Dyk, Biblijne podstawy ewangelizacji, w: Świadectwo w służbie ewangelizacji, red. W. Przygoda, Lublin 2012, s. 31-53; P. Spyra, Kerygmat Jezusa..., "Rocznik Teologii Katolickiej” t. XIII (2014) 1, s. 222-227;

51 U. Terrinoni, Nauczanie ewangeliczne, dz. cyt., s. 27-31; H. Sławiński, Przepowiadanie Chrystusowego krzyża, Warszawa 1997, s. 155-156; S. Haręzga, Jezus i Jego uczniowie..., dz. cyt., s. 199-266. 


\section{Orędzie głoszone przez Jezusa Chrystusa}

\section{Streszczenie}

Artykuł niniejszy, zatytułowany Orędzie głoszone przez Jezusa Chrystusa, omawia akt, treść i formę zbawczego przepowiadania, przez które Bóg zwraca się do człowieka, oczekując jego odpowiedzi. Centralnym tematem orędzia jest królestwo Boże oraz zawarta w nim świadomość boskiego synostwa i mesjańskiego posłannictwa. Jezus nie tylko głosił, ale sam był Ewangelią i ewangelizatorem, żył tym, co głosił i głosił to, czym żył. Jest nauczycielem, który nie proponuje doktryny, ale siebie samego, nowy model życia i postępowania. Jego orędzie uwolnienia z grzechu przywraca wspólnotę z Bogiem i braćmi, daje nowe życie.

Słowa kluczowe

orędzie Jezusa, kerygmat, królestwo Boże, przypowieści, mesjańskie posłannictwo, przepowiadania, zbawienie

\section{The message proclaimed by Jesus Christ}

\section{Summary}

This article, entitled The message proclaimed by Jesus Christ describes the action, the contents and the form of the salvific proclamation which God uses to address the human being and awaits his response. The Kingdom of God with its awareness of the divine sonship and messianic mission is the central theme of the message. Jesus not only proclaimed the message but $\mathrm{He}$ Himself was the Gospel which He proclaimed, He practiced what He preached and preached what He practiced. He is the teacher who does not propose the doctrine but Himself. He proposes the new model of life and conduct. His message of freedom from sin restores the union with God and brothers, it gives a new life.

Keywords

message of Jesus, kerygma, Kingdom of God, parables, messianic mission, preaching, salvation 


\section{Bibliografia}

Adamczyk B., Model pedagogii Jezusa w przekazie biblijnym, Kraków 2008.

Chmiel J., Pojęcie i rola kerygmatu w pierwotnym Kościele, „Ruch Biblijny i Liturgiczny" 33 (1980) nr 1, s. 59.

Dyk S., Biblijne podstawy ewangelizacji, w: Świadectwo w służbie ewangelizacji, red. W. Przygoda, Lublin 2012, s. 31-53.

Gnilka J., Jezus z Nazaretu. Orędzie i dzieje, Kraków 1997.

Haręzga S., Jezus i Jego uczniowie. Model chrześcijańskiej formacji w Ewangelii według św. Marka, Lublin 2006.

Jankowski A., Kerygmat w Kościele Apostolskim. Nowotestamentowa teologia głoszenia Słowa Bożego, Częstochowa 1989.

Kasper W., Jezus Chrystus, przeł. B. Białecki, Warszawa 1983.

Kudasiewicz J., Ewangelie synoptyczne dzisiaj, Ząbki 1999.

Mędala S., Ewangelia według świętego Jana (rozdz 1-12), Częstochowa 2010, s. 49.

Paciorek A., Kerygmat, w: Encyklopedia Katolicka, T. 8, k. 1360-1362, Lublin 2000.

Prado Flores J. H., Cómo Evangelizar a los Bautizados, México 2013.

Prado Flores J. H., Jak ewangelizować ochrzczonych, przeł. K. Skorulski, Łódź 1993.

Ptak R., Królestwo Boże - realizacja zbawczego planu Boga. Od "Lumen gentium" do "Novo millennio ineunte", Kraków 2006.

Ratzinger Joseph - Benedykt XVI, Jezus z Nazaretu, cz 1: Od chrztu w Jordanie do Przemienienia, przeł. W. Szymona, Kraków 2007.

Sławiński H., Przepowiadanie Chrystusowego krzyża, Warszawa 1997.

Spyra P., Kerygmat Jezusa - Dobra Nowina o człowieku i dla człowieka, „Rocznik Teologii Katolickiej" t. XIII (2014) 1, s. 221-240.

Terrinoni U., Nauczanie ewangeliczne w zarysie, przeł. R. Jaremko, Kraków 2000.

Tresmontant C., Jezus naucza, przeł. L. Rutowska, Warszawa 1973.

Vermes G., Autentyczna Ewangelia Jezusa, przeł. J. Kołak, Kraków 2009.

Włodarczyk S., Dialog jako metoda nauczania Jezusa, "Pedagogika Katolicka” 8 (2011) nr 1, s. 78-83.

Włodarczyk S., Trudny dialog. Droga do wiary w Chrystusa Zbawiciela, Częstochowa 2003. 